\title{
STRATEGI KEPALA SEKOLAH DALAM MENGEFEKTIFKAN KINERJA TENAGA PENDIDIK DAN KEPENDIDIKAN DI SMA NEGRI 2 PARE KABUPATEN KEDIRI
}

\author{
Fatahuddin.M.Pd.I ${ }^{1}$ \\ Fatahimron12@gmail.com
}

\begin{abstract}
Abstrak
Dalam upaya mengefektifkan kinerja pendidik dan kependidikan, kepala sekolah dituntut mampu mengembangkan berbagai upaya terobosan untuk meningkatkan kualitas dan efektivitas kinerja pendidik dan tenaga kependidikan. Upaya kepala sekolah dalam mengefektifkan pendidik dan tenaga kependidikan adalah kepala sekolah berperan sebagai pendidik, manajer, administrator, supervisor, pemimpin, inovator dan sebagai motivator. Faktor pendukung: jumlah tenaga pengajar dan kependidikan yang banyak, jumlah siswa yang banyak, sarana dan prasarana yang lengkap, status sekolah negeri. Sedangkan faktor penghambatnya antara lain konflik antar anggota organisasi sekolah, rumitnya masalah pelayanan, administrasi inventarisasi barang, dan kurangnya dukungan masyarakat. tuntas, meningkatkan prestasi pendidik dan tenaga kependidikan, meningkatkan prestasi akademik dan nonakademik pendidik dan tenaga kependidikan baik di tingkat daerah maupun nasional.
\end{abstract}

Kata Kunci: Efektivitas Kinerja, Pendidik

\footnotetext{
${ }^{1}$ IAI Hasanuddin Pare
} 


\begin{abstract}
.Abstract
In an effort to streamline the performance of educators and education, school principals are required to be able to develop various breakthrough efforts to improve the quality and effectiveness of the performance of educators and education personnel. The principal's efforts in making educators and education staff effective are that the principal acts as an educator, manager, administrator, supervisor, leader, innovator and as a motivator. Supporting factors: large number of teaching and educational staff, large number of students, complete facilities and infrastructure, state school status. While the inhibiting factors include conflicts between members of the school organization, the complexity of service problems, the administration of inventory of goods, and the lack of community support. complete, increasing the achievements of educators and education staff, increasing the achievements of academic and non-academic educators and education personnel both at the regional and national levels.
\end{abstract}

Keywords: Performance Effectiveness, Educators.

\title{
A. Pendahuluan
}

Tenaga pendidik dan kependidikan mempunyai peran yang sangat upaya-upayanya dalam pembentukan pengetahuan, ketrampilan, dan karakter peserta didik. Oleh karena itu tenaga kependidikan yang profesional akan melaksanakan tugasnya secara profesional sehingga menghasilkan tamatan yang lebih bermutu. Menjadi tenaga pendidik dan kependidikan yang profesional tidak akan terwujud begitu saja tanpa adanya upaya untuk meningkatkannya. Adapun salah satu cara untuk mewujudkannya adalah dengan pengembangan profesionalisme tenaga pendidik dan kependidikan, ini membutuhkan dukungan dari pihak yang mempunyai peran penting dalam hal ini adalah kepala sekolah, dimana kepala sekolah merupakan pimpinan pendidikan yang sangat penting karena kepala sekolah berhubungan langsung dengan pelaksanaan program pendidikan di sekolah. ${ }^{2}$

Ketercapaian tujuan pendidikan sangat bergantung pada kecakapan dan kebijaksanaan kepala sekolah merupakan seorang pejabat yang profesional dalam organisasi sekolah yang bertugas mengatur semua sumber organisasi dan bekerjasama dengan tenaga pendidik dan kependidikan dalam mendidik siswa untuk mencapai tujuan pendidikan. Dengan keprofesionalan kepala sekolah ini pengembangan profesionalisme tenaga pendidik dan kependidikan mudah dilakukan karena sesuai dengan fungsinya, kepala sekolah memahami kebutuhan sekolah yang di pimpin sehingga kompetensi guru tidak hanya stagnan (terhenti) pada kompetensi yang memiliki sebelumnya, melainkan bertambah dan berkembang dengan baik sehingga keefektifan kinerja pendidik dan tenaga kependidikan akan terwujud.

Mengacu pada pentingnya posisi upaya-upaya seorang kepala sekolah, ada kata pepatah "Lebih baik menjadi kepala udang dari pada menjadi kepala harimau" Kata tersebut

\footnotetext{
${ }^{2}$ Marihot Manullang, Manajemen Personalia. Yogyakarta:Gadjah Mada University Press,2006),hal.18.
} 
menggambarkan betapa pentingnya kedudukan/posisi kepala sekolah. Kata Kepala disini tentu tidak hanya dimaknai secara verbal akan tetapi lebih jauh lagi dapat dipahami bermakna pemimpin. Pemimpin ibarat kepala dalam posisi struktur faat tubuh manusia. Hal ini menggambarkan posisi seorang pemimpin yang sangat vital. ${ }^{3}$ Dalam sebuah lembaga pendidikan posisi seorang pemimpin juga demikian pentingnya. Seorang pemimpin akan menentukan kualitas lembaga pendidikan secara menyeluruh peran penting pemimpin dalam sebuah lembaga pendidikan sebagaimana posisi penting kepala dalam tubuh manusia. Itulah sebabnya seorang pemimpin dalam sebuah lembaga pendidikan sering disebut kepala sekolah. Betapa gambaran ini sangat tepat.

Pemimpin akan menjadi penentu kelancaran,keberhasilan dan kesuksesan sebuah lembaga pendidikan dalam mengaktualisasikan program-programnya. Pemimpin sebagai model dalam sebuah lembaga pendidikan memberikan keteladanan kepada bawahan atau orang yang dipimpinnya.SMA Negeri 2Pare kab. Kediri merupakan sekolah lanjutan yang favorit didaerah Pare dan sekitarnya. Selain tempatnya yang sangat strategis juga karena tenaga pendidik dan kependidikanya memiliki kinerja yang sangat bagus. Sehingga proses pembelajarannya berjalan dengan tertib dan berkualitas. Hal ini dapat diidentifikasikan dari jumlah siswa yang besar setiap rombongan belajarnya, juga dapat diketahui dari jumlah pendaftar yang terus meningkat setiap tahun ajaran baru, sehingga di berlakukan seleksi penerimaan siswa baru yang sangat ketat guna membatasi jumlah siswa yang dapat diterima.

Jumlah siswa yang besar salah satu indikator dari tingkat kepercayaan masyarakat yang tinggi untuk menyekolahkan anaknya dilembaga ini.Sudah tidak terbantahkan lagi jika kepercayaan yang tinggi.Kualitas yang tinggi tidak dapat dicapai dengan gratis, berpangku tangan saja.Kualitas yang tinggi mengindikasikan tingkat kinerja dari pendidik dan kependidikan yang juga tinggi.Konsekuensi jumlah siswa yang banyak diantaranya membutuhkan kelas yang banyak tenaga pendidik dan kependidikan yang banyak pula.Tingkat pelayanan yang $\mathrm{p}$ (rima serta manajemen yang bagus, tenaga keamanan yang memadai,tenaga kebersihan yang cukup,serta masih banyak pula.Rumitnya system yang demikian kompleks tersebut tidak dapat dilepaskan dari peran dan fungsi seorang kepala sekolah sebagai top leader dalam memanange dan mengorganisasikan seluruh komponen yang terlibat di dalamnya. Oleh karena itu sangat menarik untuk diteliti dengan tema:STRATEGI KEPALA SEKOLAH DALAM MENGEFEKTIFKAN KINERJA TENAGA PENDIDIK DAN KEPENDIDIKAN DI SMA NEGRI 2 PARE KABUPATEN KEDIRI.

\section{Kepala sekolah}

Kepala Sekolah merupakan salah satu komponen pendidikan yang paling berperan dalam meningkatkan kualitas pendidikan.Sebagaimana dikemukakan dalam pasal 12 ayat $1 \mathrm{PP}$

\footnotetext{
${ }^{3}$ Dessler,Gerry.Manajemen Personalia, Teknik dan konsep(Jakarta:Erlangga 1992), hal 12
} 
28 tahun 1990 bahwa Kepala Sekolah bertanggung jawab atas penyelenggaraan kegiatan pendidikan administrasi Sekolah, pembinaan tenaga kependidikan laenya, dan pendayagunaan laennya serta pemeliharaan sarana dan prasarana. ${ }^{4}$ Namun kenyataan dilapangan masih banyak kepala sekolah yang tidak menjalankan tugas dan fungsinya sebagai pemimpin pendidikan ini disebabkan karena dalam proses pengangkatannya tidak ada transparasi, rendahnya mental kepala sekolah yang ditandai dengan kurangnnya motivasi dan semangat serta kurangnya disiplin dalam melakukan tugas, dan seringnya datang terlambat mengimplikasikan rendahnya produktifitas kerja kepala sekolah yang berimplikasi juga pada mutu.

Kepemimpinan merupakan salah satu faktor yang sangat penting dalam suatu organisasi karena sebagian besar keberhasilan dan kegagalan suatu organisasi ditentukan oleh kepemimpinan dalam organisasi tersebut. Pentingnya kepemimpinan seperti yang dikemukakan oleh James L. Black pada manejemen: a.Guide to Executive Command dalam Sadili Samsuddin, yang dimaksud dengan kepemimpinan adalah kemampuan meyakinkan dan menggerakkan orang laen agar mau bekerja sama di bawah kepemimpinannya sebagai suatu tim untuk mencapai tujuan tertentu. ${ }^{5}$ Kepemimpinan kepala sekolah berarti suatu bentuk kemampuan dalam memimpin anggota suatu lembaga sekolah untuk selalu mengefektifkan kinerja tenaga pendidik dan kependidikan yang bertujuan agar kualitas dalam menjalankan dan memimpin segala sumber daya yang ada pada suatu sekolah untuk mau bekerja mencapai tujuan bersma

\section{Kepemimpinan Kepala Sekolah}

Kepala Sekolah merupakan salah satu komponen pendidikan yang paling berperan dalam meningkatkan kualitas pendidikan. Untuk itu kepala sekolah harus mengetahui tugastugas-tugas yang harus dilaksankan. Adapun tugas-tugas dari kepala sekolah seperti yang dikemukakan Wahjosumidjo adalah:

a) Kepala Sekolah bekerja dengan dan melalui orang laen.Kepala sekolah berprilaku sebagai saluran komunikasi dilingkungan sekolah.

b) Kepala Sekolah bertanggung jawab dan mempertanggung jawabkan. Kepala Sekolah bertindak dan bertanggung jawab atas tindakan dan bertanggung jawab atas segala tindakan yang dilakukan oleh bawahan.Perbuatan yang dilakukan oleh guru,siswa,staf, dan orang tua siswa tidak dapat dilepaskan dari tanggung jawab kepala sekolah.

c) Dengan waktu dan sumber yang terbatas seorang kepala sekolah harus mampu menghadapi berbagai persoalan.Dengan segala keterbatasan,seorang kepala sekolah harus dapat mengatur pemberian tugas secara cepat dan tepat dan dapat memprioritaskan bila terjadi konflik antara kepentingan bawahan dengan kepentingan sekolah.

\footnotetext{
${ }^{4}$ Tim redaksi nuansa aulia, Himpunan perundang-undangan RI Tentang Sisdiknas,Dilengkapi Peraturan Perundangan Terkait(Bandung:Nuansa Aulia,2008)hal.67

${ }^{5}$ Sadili Smsudin.Manajemen Sumber Daya Manusia.(Bandung:CV Pustaka Setia,2006),hlm 11
} 
d) Kepala Sekolah harus berfikir secara analitik dan konsepsional.Kepala sekolah harus dapat memecahkan persoalan melalui satu analisis, kemudian menyelesaikan persoalan dengan satu solusi yang fleksible. Serta harus dapat melihat setiap tugas sebagai satu keseluruhan yang saling berkaitan.

e) Kepala sekolah adalah seorang mediator atau juru menengah. Dalam linegkungan sekolah sebagai suatu organisasi di dalamnya terdiri dari manusia yang mempunyai latar belakang yang berbeda-beda yang bisa menimbulkan konflik untuk itu kepala sekolah harus jadi penengah dalam konflik tersebut.

f) Kepala sekolah adalah seorang politisi. Kepala sekolah harus dapat membangun hubungan kerjasama melalui pendekatan persuasif dan kesepakatan. Peran politis kepala sekolah dapat berkembang secara efektif, apabila: (1) dapat dikembangkan prinsip jaringan saling pengertian terhadap kewajiban masing-masing,(2) terbentuknya aliasi atau koalisi, seperti organisasi profesi,OSIS, komite sekolah, dan sebagainya, (3) terciptanya kerjasama dengan berbagai pihak, sehingga aneka macam aktivitas dapat di laksanakan.

g) Kepala Sekolah adalah seorang diplomat. Dalam berbagai macam pertemuan kepala sekolah adalah wakil resmi sekolah yang dipimpimpinnya

h) Kepala sekolah mengambil keputusan-keputusan sulit. Tidak ada organisasipun yang berjalan mulus tanpa problem. Demikian pun sekolah sebagai suatu organisasi tidak luput dari persoalan dan kesulitan-kesulitan. Dan apabila terjadi kesulitan-kesulitan kepala sekolah diharapkan berperan sebagai orang yang dapat menyelesaikan persoalan yang sulit tersebut. ${ }^{6}$

Kepemimpinan kepala sekolah berarti suatu bentuk kemampuan dalam memimpin anggota suatu lembaga sekolah untuk selalu kinerja tenaga pendidik dan kependidikan yang bertujuan agar kualitas dalamn menjalankan dan memimpin segala sumber daya yang ada pada suatu sekolah untuk mau bekerja sama dalam mencapai tujuan bersama.Kepala Sekolah merupakan salah satu komponen pendidikan yang paling berperan dalam meningkatkan kualitas pendidikan.Untuk itu Kepala Sekolah harus mengetahui tugas-tugas yang harus dilaksanakan.

\section{Efektifitas Kinerja Tenaga Pendidik Dan Kependidikan}

Menurut peraturan Pemerintah Republik Indonesia Nomer 38 tahun 1992 tentang tenaga kependidikan bahwa jenis tenaga kependidikan disebutkan terdiri atas tenaga kependidikan, pengelola satuan pendidikan,penilik,pengawas,peneliti dan pengembang dibidang belajar.Tenaga pendidik terdiri atas pembimbing ,pengajar dan pelatih.Pengelola satuan pendidikan terdiri atas kepala sekolah,direktor,ketua,rektor dan pimpinan satuan

\footnotetext{
${ }^{6}$ Wahjosumidjo.Kepemimpinan Kepala Sekolah,hlm.97
} 
pendidikan luar sekolah (pasal3,42). ${ }^{7}$ Secara umum tenaga kependidikan adalah orang-orang yang bekerja dalam dunia pendidikan yang memiliki syarat-syarat tertentu.Orang-orang inilah yang akan menjalankan dan menjadi motor bagi dunia pendidikan.

Dalam tataran mikro teknis, guru sebagai tenaga pendidik merupakan pimpinan pendidikan, dia amat menentukan dalam proses pembelajaran di kelas dan kepemimpinan tersebut akan tercermin dari bagaimana guru melaksanakan peran dan tugasnya, ini berarti bahwa kinerja guru merupakan faktor yang amat menentukan bagi mutu pembelajaran/pendidikan yang akan berimplikasi pada kualitas output pendidikan setelah menyelesaikan sekolah. ${ }^{8}$

Kinerja guru pada dasarnya merupakan kinerja atau unjuk kerja yang dilakukan oleh guru dalam melaksanakan tugasnya sebagai pendidik.Kualitas kinerja guru akan sangat menentukan pada kualitas hasil pendidik, karena guru merupakan fihak yang paling banyak bersentuhan langsung dengan siswa dalam proses pendidikan di lembaga pendidikan Sekolah.Berikut pendapat para ahli terkait dengan kinerja.

a. Performance diartikan sebagai hasil pekerjaan, atau pelaksanaan tugas pekerjaan,(Menurut Pariata Westra dalam Kusnandar). ${ }^{9}$

b. Kinerja adalah proses kerja dari seorang individu untuk mencapai hasil-hasil tertentu,(Menurut Bateman dalam Kusnandar). ${ }^{10}$

c. Prestasi kerja atau penampilan kerja diartikan sebagai ungkapan kemampuan yang didasari oleh pengetahuan, sikap, dan ketrampilan dan motivasi dalam menghasilkan sesuatu,(Menurut Nanang Fattah) ${ }^{11}$

d. Performance is defined as the record of outcomes produced on aspecified job function or activity during a specific time period (Bernardin dan Russel dalam Farida $^{12}$

e. Kinerja (prestasi kerja) adalah hasil kerja secara kualitas dan kuantitas yang dicapai oleh seorang pegawai dalam melaksanakan tugasnya sesuai dengan tanggung jawab yang diberikan kepadanya,(Menurut Soecipto) ${ }^{13}$

Dari beberapa pengertian kinerja di atas, penulis dapat menarik kesimpulan bahwa kinerja merupakan suatu kemampuan kerja atau prestasi kerja yang diperlihatkan oleh seorang pegawai untuk memperoleh hasil kerja yang optimal dengan demikian istilah kinerja mempunyai pengertian akan adanya suatu tindakan atau kegiatan yang ditampilkan oleh seorang dalam melaksanakan aktivitas tertentu.Kinerja seseorang akan nampak pada situasi

\footnotetext{
${ }^{7}$ Tim Redaksi Nuansa Aulia,Himpunan Perundang-undangan RI Tentang Sisdiknas, hlm.78

${ }^{8}$ Hartini Sukirman.Manajemen Tenaga Pendidikan, hal.55

${ }^{9}$ Kusnandar,Guru Profesional,(Jakarta:PT Raja Grafindo,2007), hal 246.

${ }^{10}$ Kusnandar.Guru Profesional,hlm.247

${ }^{11}$ Fatah Nanang Landasan Manajemen Pendidikan.(BandungRosdakarva,1998), hal 19

12 Farida Sarimaya,Sertifikasi Guru:Apa,Mengapa,dan Bagaimana?,(Yrama Widja:Bandung,2008),Hal 15

${ }^{13}$ Soetjipto, Kosasaih.Profesi Keguruan.(Jakarta:Rineka Cipta,1999),hlm.97
} 
dan kondisi kerja sehari-hari. Aktivitas-aktivitas yang dilakukan oleh seorang dalam melaksanakan pekerjaannya menggambarkan bagaimana ia berusaha mencapai tujuan yang telah ditetapkan. Menurut A.Dele Timpe dalam bukunya performance sebagaimana dikutip oleh Ch. Suprapto dikemukakan bahwa kinerja adalah akumulasi dari tiga element yang saling berkaitan yaitu ketrampilan,upaya,dan sifat-sifat keadaan eksternal. ${ }^{14}$ Ketrampilan dasar yang dibawa seseorang ke tempat pekerjaan dapat berupa pengetahuan,kemampuan,kecakapan,interpersonal dan kecakapan teknis.

\section{Upaya-upaya Kepala Sekolah Dalam mengefektifkan Kinerja Tenaga Pendidik Dan Kependidikan Di SMA Negeri 2 Pare Kabupaten Kediri}

Sebagai Kepala Sekolah ataupun pemimpin, kepala sekolah harus harus dapat meningkatkan mutu sekolah yang dipimpinnya agar tercapai suatu tujuan yang diinginkan.Hal ini sejalan dengan yang diungkapkan oleh Wahjosumidjo bahwa kepala sekolah dapat didefinisikan sebagai seorang tenaga fungsional guru yang diberi tugas untuk memimpin suatu sekolah dimana diselenggarakan proses belajar mengajar, atau tempat di mana terjadi interaksi antara pendidik yang memberi pelajaran dan murid yang menerima pelajaran

Berdasarkan pengertian diatas bahwa kepala sekolah itu mempunyai tugas memimpin maka kepala sekolah itu merupakan kekuatan sentral yang mampu mempengaruhi dan menggerakkan orang lain untuk mencapai suatu tujuan dengan irama yang diciptakan. Hal ini juga diperkuat oleh mulyasa yang menjelaskan, dalam paradigma baru manajemen pendidikan kepala sekolah sedikitnya harus mampu berfungsi sebagai educator,manajer,administrator,supervisor,leader,inovator,motivator (EMASLIM). Ada beberapa upaya-upaya kepala sekolah, yang telah dilakukan untuk mengefektifkan kinerja pendidik dan tenaga kependidikan, antara laen

\section{Kepala sekolah sebagai Educator (pendidik)}

Dalam fungsinya sebagai educator, kepala sekolah telah melakukan upaya-upaya yang tepat untuk meningkatkan profesionalisme tenaga kependidikan disekolah. Menciptakan iklim sekolah yang kondusif, memberikan nasehat kepada warga sekolah. Terutama kepada tenaga pendidik dan tenaga kependidikan.Peran kepala sekolah sebagai pendidik, harus mampu menanamkan pembinaan moral, yaitu pembinaan-pembinaan para tenaga kependidikan tentang hal-hal yang berkaitan dengan ajaran baik buruk mengenai suatu perbuatan,sikap, dan kewajiban masing-masing. Kepala sekolah profesional harus berusaha memberikan nasehat kepada seluruh warga sekolah disetiap kesempatan, misalnya pada setiap upacara bendera atau pertemuan rutin, dirapat-rapat atau kesempatan yang lain.

\section{Kepala Sekolah sebagai Manajer}

\footnotetext{
${ }^{14}$ Timpe,Dale.Sari Ilmu dan seni manajemen Bisnis Kepemimpinan ,(Jakarta:Gramedia,1991),hlm 14
} 
Dikatakan sebagai manajer adalah seseorang yang bertanggung jawab untuk mencapai hasil tertentu melalui tindakan orang lain yang berada dibawah tanggung jawabnya. Sebagai manajer, Kepala Sekolah telah melakukan upaya-upaya yang tepat untuk memberdayakan tenaga kependidikan melalui kerjasama atau kooperatif, memberikan kesempatan kepada para tenaga pendidik dan kependidikan untuk selalu meningkatkan profesionalitasnya, dan mendorong ketertiban seluruh tenaga pendidik dan kependidikan dalam berbagai kegiatan yang menunjang program sekolah.

Manajemen pada hakekatnya merupakan suatu proses merencanakan, mengorganisasikan, melaksanakan, memimpin dan mengendalikan usaha para anggota organisasi serta mendayagunakan seluruh sumber-sumber daya organisasi dalam rangka mencapai tujuan yang telah ditetapkan. Dikatakan suatu proses, karena semua manajer dengan ketangkasan dan ketrampilan yang dimilikinya mengusahakan dan mendayagunakan berbagai kegiatan yang saling berkaitan untuk mencapai tujuan.

Berdasarkan uraian tersebut,seorang manajer atau, Kepala Sekolah pada hakekatnya adalah seorang perencana, organisator,pemimpin, dan seorang pengendali. Keberadaan manajer pada suatu organisasi seperti sekolah sangat diperlukan, sebab organisasi sebagai alat mencapai tujuan organisasi dimana didalamnya berkembang berbagai macam pengetahuan, serta organisasi yang menjadi tempat untuk membina dan mengembangkan berbagai potensi atau karier sumber daya manusia, memerlukan manajer yang mampu untuk merencanakan, mengorganisasikan, memimpin dan mengendalikan agar organisasi dapat mencapai tujuan yang telah ditetapkan.

\section{Kepala Sekolah sebagai Administrator}

Kepala Sekolah Sebagai Administrator memiliki hubungan yang sangat erat dengan berbagai aktifitas pengelolaan administrasi yang bersifat pencatatan, menyusun dan pendokumenan seluruh program sekolah. Sebagai seorang administrator, Kepala Sekolah harus memiliki kemampuan untuk memperbaiki dan mengembangkan semua fasilitas sekolah baik sarana maupun prasarana pendidikan.Peran Kepala Sekolah sebagai administrator dapat dilihat pada kemampuan pengelolaan kurikulum, pengelolaan personalia, pengelolaan sarana dan prasarana, pengelolaan administrasi kearsipan, administrasi tata usaha, dan pengelolaan administrasi keaungan.

Dalam melaksanakan tugas-tugas diatas, kepala sekolah sebagai administrator, khususnya dalam meningkatkan kinerja dan produktifitas sekolah, dapat dianalisis berdasarkan beberapa pendekatan, baik pendekatan sifat, pendekatan prilaku, maupun pendekatan situasional. Dalam hal ini, kepala sekolah harus mampu bertindak situasional, sesuai dengan situasi dan kondisi yang ada. Meskipun demikian, pada hakekatnya kepala sekolah harus lebih mengutamakan tugas, agar tugas-tugas yang diberikan kepada setiap tenaga kependidikan bisa dilaksanakan dengan sebaik-baiknya. Dengan demikian, efektifitas kerja Kepala Sekolah bergantung pada tingkat pembauran antara gaya kepemimpinan dengan tingkat menyenangkan dalam situasi tertentu.

4. Kepala Sekolah sebagai Supervisor 
Kegiatan utama pendidikan disekolah dalam rangka mewujudkan tujuannya adalah kegiatan, sehingga seluruh aktifitas organisasi sekolah bermuara pada pencapaian efisiensi dan efektifitas pembelajaran. Oleh karena itu, salah satu tugas Kepala Sekolah adalah sebagai supervisor, yaitu mensupervisi pekerjaan yang dilakukan oleh tenaga pendidik dan kependidikan. Kepala Sekolah sebagai supervisor harus diwujudkan dalam kemampuan menyusun, dan melaksanakan program supervisi pendidikan, serta memanfaatkan hasilnya.

Kepala Sekolah sebagai supervisor dimaksudkan untuk menigkatkan pengawasan dan pengendalian terhadap guru-guru dan personel lain untuk meningkatkan kinerjanya. Kepala Sekolah bertugas mengatur seluruh aspek kurikulum yang berlaku disekolah sesuai dengan target yang telah yang telah ditentukan.Peran utama Kepala Sekolah sebagai supervisor adalah menyusun dan melaksanakan program supervisi pendidikan serta memanfaatkan hasilnya yang diwujudkan dalam program supervisi kelas, kegiatan ssktra kurikuler, serta peningkatan kinerja tenaga kependidikan dalam upaya pengembangan sekolah.

\section{Kepala Sekolah Sebagai Pemimpin}

Kepala Sekolah Sebagai pemimpin harus mampu memberikan petunjuk dan pengawasan, meningkatan kemampuan tenaga pendidik dan kependidikan.Ada beberapa karakter yang harus dimiliki kepala sekolah sebagai leadaer yaitu kepribadian,keahlian dasar,pengalaman dan pengetahuan profesional, serta pengetahuan administrasi dan pengawasan. Sedangkan kepribadian kepala sekolah sebagai pemimpin akan tercermin dalam sifat-sifatnya yaitu 1.Jujur 2.percaya diri 3.Tanggung jawab 4.berani mengambil resiko dan keputusan 5.berjiwa besar 6.emosi yang stabil 7.Teladan.

Disamping itu kemampuan yang harus diwujudkan kepala sekolah sebagai leader dapat dianalisis dari kepribadaian, pengetahuan terhadap tenaga pendidik dan kependidikan, visi dan misi sekolah, kemampuan mengambil keputusan, kemampuan berkomunikasi dan kemampuan untuk memahami siswa.Kepala sekolah sebagai leader harus memiliki karakter khusus yang mencakup kepribadian, keahlian dasar, pengalaman dan pengetahuan profesional, serta pengetahuan administrasi dan pengawasan. Kepala Sekolah sebagai leader memiliki visi dan mempunyai peranan dalam mengelola visi menjadi sebuah kenyataan.Untuk menjadi sebagai pemimpin yang aktif menggunakan analitis yang dikembangkan dengan benar dan baik serta kemampuan intelektual dalam membimbing para staf dalam proses mengindetifikasikan masalah-masalah ketrampilan politik dan manajemen untuk menyelesaikan konflik dan mampu membuat berbagai rencana kerja

\section{Kepala Sekolah Sebagai Innovator}

Dalam rangka melakukan peran dan fungsinya sebagai innovator,kepala sekolah harus memiliki upaya-upaya yang tepat untuk menjalin hubungan yang harmonis dengan lingkungan mencari gagasan yang baru mengintegrasikan setiap kegiatan memberikan teladan kepda seluruh warga sekolah dan mengembangkan model-model pemblajaran yang 
inovatif.kepala sekolah sebagai innovator harus mampu mencari menemukan dan melaksanakan berbagai pembaharan di sekolah.

\section{Kepala Sebagai Motivator}

Sebagai motivator, Kepala Sekolah harus memiliki upaya-upaya yang tepat untuk memberikan motivasi kepada para tenaga pendidik dan kependidikan dan para siswa dalam melakukan berbagai tugas dan fungsinya.Peran kepala sekolah sebagai motivator sangat penting dalam mengembangkan dan mencapai tujuan sekolah yang telah ditetapkan.Kepala Sekolah dalam membina staf utamanya para guru sebagai pendidik sangat penting sebab guru merupakan alat utama dalam menciptakan tujuan pemblajaran di sekolah.Dari gurulah ilmu pengetahuan akan mengalir kepada siswa.Karenanya dalam mencapai tujuan pemblajaran yang efektif dan efisien kepala sekolah sangat dituntut untuk meningkatkan profesionalisme guru.

\section{Faktor pendukung dan penghambat upaya-upaya kepala sekolah dalam mengefektifkan kinerja tenaga pendidik dan kependidikan di sma negeri 2 pare kabupaten kediri}

\section{Faktor Pendukung}

a) Jumlah tenaga pendidik dan kependidikan yang banyak

Jumlah tenaga pendidik dan kependidikan yang banyak akan sangat mendukung bagi upaya-upaya Kepala Sekolah untuk mengefektifkan kinerja tenaga pendidik dan kependidikan di sekolahnya.Hal tersebut karena dengan jumlah tenaga pendidik dan kependidikan yang banyak akan lebih memungkinkan kepala sekolah menerapkan job desciption (pembagian tugas) sesuai dengan keahlian masing-masing.Sehingga tugas yang diamanatkan akan lebih berpeluang untuk ditunaikan lebih baik.Khususnya bagi tenaga pendidik,kepala sekolah akan lebih memungkinkan untuk menyeleksi guna mendapatkan pilihan yang ideal bagi kelancaran program-programnya.Sedangkan jumlah tenaga kependidikan yang banyak juga kepala sekolah akan mampu membagi tugas-tugas yang banyak dapat terslesaikan tepat waktu.Tidak perlu jam lembur atau kerja ekstra waktu.

b) Jumlah siswa yang banyak

Di satu sisi jumlah siswa yang banyak menjadi pendukung bagi sekolah untuk mengembangkan kreatifitas dan kualitas pemblajarannya.Terutama terkait dengan usaha mengefektifkan kinerja tenaga pendidik dan kependidikan.Banyaknya siswa akan lebih memacu adrenelin tenaga pendidik dan kependidikan dan karyawan untuk bekerja lebih keras dan mengkir prestasi kerja lebih baik lagi.Selain itu jumlah siswa yang banyak juga lebih memudahkan tenaga pendidik dan pendidikan untuk menggali bakat dan potensi siswa untuk dapat di kembangkan ke arah yang lebih baek lagi. Dari sisi kesejahteraan tenaga pendidik dan 
kependidikan jumlah siswayang banyak juga sangat menguntungkan karena akan mendatangkan incame keuangan yang banyak pula

Selain itu untuk meningkatkan kompetensi tenaga pendidik dan kependidikan jumlah siswa yang banyak dapat memberikan kesempatan pada para tenaga pendidik yaitu tenaga pendidik dan kependidikan untuk ikut sertifikasi tenaga pendidik dan kependidikan dan mendapatkan tunjangan sertifikasi.Hal ini dapat dijadikan umpan balik oleh kepala sekolah untuk menekankan keefektifan kinerja tenaga pendidik dankependidikan.

c) Sarana dan prasarana yang lengkap

Sarana dan prasarana yang lengkap akan mendukung di setiap kebijakan yang diambil kepala sekolah.Setiap langkah yang akan di aplikasikan dilapangan tentu membutuhkan fasilitas dan sarana yang memadai.Oleh karena itu lengkapnya sarana dan prasarana sekolah sangat mendukung suksesnya program-program sekolah.Karena dengan saran dan prasaran yang lengkap tenaga pendidik dan kependidikan akan dapat bekerja secara efektif.

d) Status sekolah negeri

Kalau dicermati masyarakat sekarang ini dalam memilihkan anaknya dalam bersekolah masih sangat mempertimbangkan aspek status dari sekolah yang dituju.Sebagian banyak masyarakat dapat dipastikan memilih sekolah negeri untuk anak anaknya.Karena sekolah negeri di yakini memiliki fasilitas pemblajaran sarana dan prasarana yang lebih lengkap dibanding sekolah swsta.Sekolah negeri juga diyakini memiliki tenaga pendidik dan kependidikan yang lebih profesional dibanding sekolah swasta.Sekolah negeri juga dinilai memiliki tingkat kedisiplinan yang lebih baek.Juga yang tidak kalah pentingnya secara faktual sekolah negeri memiliki prestasi yang lebih baek di banding sekolah swasta.Hal ini tidak saja menyangkut nilai Ujian Nasional tetapi prestasi akademik dan non akademik secara keseluruhan.

Oleh karena itu status SMA Negeri 2Pare Kabupaten Kediri merupakan salah satu faktor pendukung untuk mengefektifkan kinerja tenaga pendidik dan kependidikan.Bagi tenaga pendidik dan kependidikan dan karyawan mengabdikan diri disekolah negeri memiliki gengsi tersendiri.Ini salah satu yang memotifasi tenaga pendidik dan kependidikan lebih memiliki dedikasi yang lebih di bandingkan sekolah swasta.

e) Letak yang strategis

Letak SMA Negeri 2Pare Kabupaten Kediri yang upaya-upaya yakni berada dipusat kota Kabupaten Kediri menjadikan daya tarik tersendiri bagi masyarakat untuk menyekolahkan anak-anaknya.Kota pare yang menjadi pusat berbagai aktifitas mulai dari pendidikan, perdagangan dan bisnis menyediakan berbagai fasilitas hidup yang lebih modern dan praktis untuk masyarakat. Hal ini membuat posisi SMA Negeri Pare Kabupaten Kediri menjadi pilihan bagi anak-anak SLTP yang ingin melanjutkan sekolahnya ke jenjang SLTA.Hal ini sangat 
menguntungkan kepala sekolah dalam mengembangkan upaya-upaya dan kebijakan untuk merebut calon-calaon siswa yang memiliki prestasi baik di sekolah asalnya.Sehingga akan lebih dapat ditingkatkan ketika mereka telah menjadi siswa SMA Negeri Pare Kabupaten Kediri.Hal tersebut menuntut kinerja yang efektif dari para tenaga pendidik dan kependidikan.Agar dikemudian hari prestasi mereka mengharumkan nama baik sekolah baik ditingkat daerah maupun ditingkat nasional.

\section{Faktor Penghambat}

a) Adanya konflik antar pribadi

Jumlah tenaga pendidik dan kependidikan yang banyak di sisi yang laen mendatangkan hambatan dan tantangan.Tenaga pendidik dan kependidikan yang banyak atau banyak membutuhkan sistem manajemen yang lebih komplek.Energi yang banyak juga membutuhkan kejelian kepala sekolah dalam memahami karakter masing-masing serta peluang konflik yang lebih banyak pula.Oleh karena itu jumlah tenaga pendidik dan kependidikan yang banyak kepiawaian dan ketangguhan dari kepala sekolah untuk menerapkan manajemen konflik, sehingga perbedaan masing-masing bawahan tidak menjadi penghambat akan Tetapi justru dapat dikemas menjadi potensi yang banyak. Dalam hal ini kepala sekolah memahaminya tantangan menjadi peluang dalam meningkatkan kinerja tenaga pendidik dan kependidikan di SMA Negeri 2 Pare Kabupaten Kediri.

b). Kompleksitas permasalahan layanan

Demikian pula halnya dengan jumlah siswa yang banyak di sati sisi menuntut kerja keras dari semua pihak utamanya dari kepala sekolah untuk mengefektifkan kinerja setiap komponen. Sehingga tercipta kekompakan kerja dari tenaga pendidik dan kependidikan secara lebih dinamis.Jumlah siswa yang banyak membutuhkan pendanaan yang banyak pula. Selain itu jumlah siswa yang banyak juga memiliki resiko kenakalan anak didik yang lebih komplek. Keseriusan dan keuletan dari kepala sekolah dalam hal ini sangat dituntut guna memberdayakan seluruh potensi yang ada.

c). Lemahnya dukungan masyarakat

Pada umumnya masyarakat yang menyekolahkan anaknya di sekolah negeri kurang memiliki tingkat dukungan yang tinggi. Hal tersebut dipengaruhi oleh banyak faktor. Di antaranya masyarakat beranggapan sekolah negeri segala sesuatunya telah ditanggung oleh negara. Teanag pendidik dan kependidikan dianggap telah memiliki kafabilitas dan tanggung jawab yang penuh. Maraknya iklan sekolah gratis juga menggeser tingkat partisipasi masyarakat pada sekolah negeri. Padahal apa yang terjadi disekolah negeri tidak sepenuhnya seperti yang diasumsikan oleh mayarakat. Oleh karena itu tanpa adanya dukungan dari masyarakat, sekolah negeri akan sangat kesulitan mengembangkan kualitas sekolahnya. (RBOS) 
d) Dana Rintisan Bantuan Operasional Sekolah

Tingginya biaya pendidikan memicutingginya angka putus sekolah pada anak didik. Hal ini menjadi hambatan tersendiri bagi sekolah negeri. Tidak adanya dana bantuan dari pemerintah yang semisal dana Rintisan Bantuan Operasional Sekolah (R-BOS), memaksa sekolah untuk pandai-pandai memeras otak agar lebih kreatif dalam mencukupi kebutuhan dana yang menjadi sumber penghidupan sekolah. Adanya tunjangan sertifikasi guru disatu sisi memang dapat meningkatkan taraf kesejahteraan guru, akan tetapi justru di sisi yang lain menjadi kecemburuan pada guru yang belum sertifikasi.

Oleh karena itu adanya iklan sekolah gratis yang pada tingkat sosialisasi tidak diikutipencerahan wawasan dari masyarakat akan justru kontra produktif bagi sekolah menengah tingkat atas atau SLTA. Jika hal tersebut tidak dapat di atasi secara sigab oleh sekolah yang bersangkutan maka tidak mustahil sekolah akan mengalami keterpurukan.

\section{B. Hasil yang dicapai dari Upaya-upaya Kepala Sekolah Dalam Mengefektifkan Kinerja Tenaga Pendidik Dan Kependidikan Di SMA Negeri 2 Pare Kabupaten Kediri.}

Tanggung jawab seorang pemimpin adalah sangat berat. Terutama dalam meningkatkan profesionalisme tenaga pendidik dan kependidikan. Di dalam memimpin seorang Kepala Sekolah harus bisa mengendalikan berbagai komponen yang berbeda, dengan fasilitas yang tersedia. Latar belakang pendidikan, budaya dan sosial serta keinginan yang berbeda-beda, yang ditampung dalam satu wadah sebuah lembaga pendidikan tentu ini akan mempengaruhi pola pikir dan perbuatan para tenaga pendidik dan kependidikan dengan orientasinya masing-masing.

Kepala Sekolah yang bijaksana akan sangat memperhatikan setiap jenis kerakter dari masing-masing tenaga pendidik dan kependidikan tersebut. Seorang Kepala Sekolah harus memahami bahwa sebuah lembaga pendidikan itu bersifat unik dan angat komplek. Dalam hal peningkatan profesionalisme tenaga pendidik dan kependidikan, Seorang Kepala Sekolah harus memiliki kebijakan yang dapat sesuai dengan karak tertenaga pendidik dan kependidikan masing-masing sehingga para tenaga pendidik dan kependidikan tersebut dapat menerima dan melaksanakan dengan senang hati dan penuh rasa tanggung jawab.benar-benar.

Kepribadianseorangpemimpinakansangatberpangaruhpadakeberhasilandalammembin abawahan. Kepemimpinan seseorangs angat terkait dengan situasi dan kondisi dihadapinya. Situasi dan kondisi itu dibagi yang tengah menjadi tiga, yaitu: pertama, Tugas pekerjaan yang dihadapi. Kedua, Orang-orang yang dipimpinnya Ketiga, Keadaan yang mempengaruhi pekerjaan tersebut. 
Pemimpin harus mengenal orang-orang yang dipimpinnya, dan mengenaldirinya, mengenal tugas pekerjaan yang akan dijalankannya serta mengenal situasi disekitarnya. Baik yang berpengaruh secara dan kondisi yang langsung maupun tidak langsung.Pemimpin harus membimbing, mengarahkan, memberi instruksi, serta mengontrol dan mengevaluasi kerja para bawahannya. Selain itu pemimpin juga harus mampu menciptakan trik dan upaya-upaya yang ampuh guna mengatasi kendala-kendala yang akan sangat mungkin terjadi di dalam menjalankan tugasnya. Pemimpin yang dalam hal ini Kepala sekolah, harus berperan sebagai pembina bagi kelompok yang dipimpinnya. Mengayomi dan melindungi para bawahan yang dipimpinnya sehingga para bawahan merasa tenang dan nyaman di dalam menjalankan tugasnya masing-masing.

Kepemimpinan menggambarkan hubungan dinamis antara tujuan pemimpin serta tujuan dan kabutuhan yang dipimpinnya. Kepemimpinan menjalankan fungsinya pada kesempatan pilihan dan perjuangan yang menjadi Cita-citakelompoknya.

Hal inilah yang juga dijalankan oleh Kepala sekolah SMA Negeri 2 Pare Kabupaten Kediri. Kepribadian yang sabar dan tenang menjadikan Kepala Sekolah SMA Negeri 2 Pare Kabupaten Kediri dapat diterima oleh semua pihak. Terutama para tenaga pendidik dan kependidikan. Hal ini merupakan modal awal bagi keberhasilan Kepala Sekolah SMA Negeri 2 Pare Kabupaten Kediri di dalam menjalankan program peningkatan profesionalisme para tenaga pendidik dan kependidikan. Banyak pemimpin yang memiliki program yang bagus namun gagal karena disebabkan kurangnya pendekatan dengan para bawahan. Selain itu gaya kepemimpinan yang demokratis telah menjadikan kedekatan antara Kepala sekolah SMA Negeri 2 Pare Kabupaten Kediri dengan para tenaga pendidik dan kependidikan terjalin dengan baik.

Kepiawaian Kepala sekolah SMA Negeri 2 Pare Kabupaten Kediri juga diterapkan terhadap para tenaga pendidik dan kependidikan yang sedang dalam masalah baik masalah pribadi maupun masalah tugas, selalu berusaha untuk membantunya.

Dalam meningkatkan profesionalisme tenaga pendidik dan kependidikan, kepala sekolah menitik beratkan peningkatan pada aspek 4 (empat) kompetensi tenaga pendidik dan kependidikan, yaitu kompetensi Kepribadian, pedagogis, professional dan social. Keempat kompetensi tersebut akan sangat berpengaruh dalam peningkatan profesionalisme tenaga pendidik dan kependidikan di SMA Negeri 2 Pare Kabupaten Kediri.

Dari beberapaupaya-upaya yang telahdijalankanolehKepalaSekolah SMA Negri 2.Kabupaten Kediri telahmembawakaberhasilanterkaitpeningkatankinerjapendidikdantenagakependidikan.Keberh asilantersebut di antaranyaadalahsebagaimanatercantumdalamtabelberikut:

\section{Daftar Prestasi Tenaga Pendidik Dan Kependidikan SMA Negeri 2 Pare}




\begin{tabular}{|c|c|c|c|c|c|c|}
\hline No. & $\begin{array}{c}\text { NamaTenagaPend } \\
\text { idiikdanKependid } \\
\text { ikan }\end{array}$ & $\begin{array}{c}\text { NamaPre } \\
\text { stasi }\end{array}$ & $\begin{array}{c}\text { Akademik/ } \\
\text { Non } \\
\text { Akademik }\end{array}$ & Tahun & Penyelenggara & Tingkat \\
\hline 1. & Drs.H.Muh.Tamziy & $\begin{array}{l}\text { Tenaga } \\
\text { pendidik } \\
\text { dan } \\
\text { kependidi } \\
\text { kan III } \\
\text { tingkat } \\
\text { Kabupaten }\end{array}$ & Akademik & 1998 & Bupati Kediri & $\begin{array}{l}\text { Kabi/Kot } \\
\text { a }\end{array}$ \\
\hline 2. & $\begin{array}{l}\text { Drs.Mansyhuri,M. } \\
\text { Pd.I }\end{array}$ & $\begin{array}{l}\text { Tenaga } \\
\text { pendidik } \\
\text { dan } \\
\text { kependidi } \\
\text { kan } \\
\text { teladan }\end{array}$ & Akademik & 1999 & Bupati Kediri & $\begin{array}{l}\mathrm{Kab} / \mathrm{KoT} \\
\mathrm{A}\end{array}$ \\
\hline 3. & $\begin{array}{l}\text { Drs.Mansyhuri,M. } \\
\text { Pd.I }\end{array}$ & $\begin{array}{l}\text { Tenaga } \\
\text { pendidik } \\
\text { dan } \\
\text { kependidi } \\
\text { kan } \\
\text { berprestasi } \\
\text { juara III }\end{array}$ & Akademik & 2004 & Bupati Kediri & $\begin{array}{l}\mathrm{Kab} / \mathrm{KoT} \\
\mathrm{A}\end{array}$ \\
\hline 4. & $\begin{array}{l}\text { Drs.Mansyhuri,M. } \\
\text { Pd.I }\end{array}$ & $\begin{array}{l}\text { Tenaga } \\
\text { pendidik } \\
\text { dan } \\
\text { kependidi } \\
\text { kan } \\
\text { teladan 1 } 1 \\
\text { Kabupaten }\end{array}$ & Akademik & 2007 & $\begin{array}{l}\text { Depag } \\
\text { Kab.Kediri }\end{array}$ & $\begin{array}{l}\mathrm{Kab} / \mathrm{KoT} \\
\mathrm{A}\end{array}$ \\
\hline 5. & $\begin{array}{l}\text { Drs.Mansyhuri,M. } \\
\text { Pd.I }\end{array}$ & $\begin{array}{l}\text { Tenaga } \\
\text { pendidik } \\
\text { dan } \\
\text { kependidi } \\
\text { kan } \\
\text { teladan } 1 \\
\text { Jawa } \\
\text { Timur } \\
\end{array}$ & Akademik & 2012 & $\begin{array}{l}\text { Depag } \\
\text { Kab.Kediri }\end{array}$ & $\begin{array}{l}\mathrm{Kab} / \mathrm{KoT} \\
\mathrm{A}\end{array}$ \\
\hline
\end{tabular}

Dari tabel di atas sangatlah tampak bahwa para tenaga pendidik dan kependidikan di SMA Negeri 2 Pare Kabupaten Kediri memiliki kinerja yang terus meningkat dari tahun ke tahun. Maka tidak aneh jika prestasi siswanya juga terus mengalami peningkatan. Tidak hanya prestasi akademik akan tetapi juga prestasi non akademik. Pada tahun 2012 SMAN 2 Pare berhasil memberangkatkan anak didiknya ke Singapura sebagai duta pelajar. Selain itu tidak kurang dari 230 anak yang berhasil memasuki perguruan tinggi favorit baik di Jawa Timur 
maupun di luar Jawa Timur. Sebanyak 73 anak lulus melalui jalur undangan Seleksi Nilai Masuk Perguruan Tinggi Negeri (SNMPTN). Sedangkan sisanya melalui tes murni. Anak-anak tersebut tersebar mulai di Institut Teknologi Surabaya (ITS), UNAIR, Universitas Brawijaya (UNBRA), Universitas Malang (UM), Universitas Negeri Surabaya (UNESA), Universitas Jember (UNEJ), dan Universitas Indinesia (UI).

\section{Kesimpulan dan Saran}

\section{Kesimpulan}

1. Upaya-upaya kepala sekolah dalammengefektifkan kinerja tenaga pendidik dan kependidikan di SMA Negeri 2 Pare Kabupaten Kediri relatif bervariasi dalam perspektif peran.Artinya, bahwa dalam kegiatan usahanya mengefektifkan kinerja maka kepala sekolah secara situasional berperan sebagai educator, manager, administrator, pemimpin, innovator sekaligus motivator

2. Faktor pendukung dan penghambat upaya upaya kepala sekolah dalam mengefektifkan kinerja tenaga pendidik dan kependidikan Di SMA Negeri 2 Pare Kabupaten Kediri.

a. Faktor pendukung:

1) Jumlah tenaga pendidik dan kependidikan yang besar.

2) Jumlah siswa yang besar.

3) Sarana dan prasarana yang banyak

4) Status sekolah negeri

b. Faktor penghambat:

1). Adanya konflik antar anggota organisasi sekolah.

2). Kompleksitas permasalahan layanan

3). Administrasi inventarisasi barang

4). Lemahnya dukungan masyarakat

3. Hasil yang dicapai dari upaya-upaya Kepala Sekolah Dalam Mengefektifkan Kinerja Tenaga Pendidik Dan Kependidikan Di SMA Negeri 2 Pare Kabupaten Kediri adalah:

a. Jumlah siswa yang terus meningkat.

b. Pemenuhan sarana dan prasarana yang lengkap 
c. Peningkatan jenjang taraf pendidikan para tenaga pendidik dan kependidikan.

d. Peningkatan prestasi tenaga pendidik dan kependidikan akademik dan non akademik baik ditingkat daerah maupun ditingkat Nasional.

b. Faktor penghambat:

1). Adanya konflik antar anggota organisasisekolah.

2). Kompleksitas permasalahan layanan

3). Administrasi inventarisasi barang

4). Lemahnya dukungan masyarakat

3. Hasil yang dicapai dari upaya-upaya Kepala Sekolah Dalam Mengefektifkan Kinerja Tenaga Pendidik Dan Kependidikan Di SMA Negeri 2 Pare Kabupaten Kediri adalah:

a. Jumlah siswa yang terus meningkat.

b. Pemenuhan sarana dan prasarana yang lengkap

c. Peningkatan jenjang taraf pendidikan paraTenaga pendidik dan kependidikan.

d. Peningkatan prestasi tenaga pendidik dan kependidikan akademik dan non akademik baik ditingkat daerah maupun ditingkat Nasional.

\section{Saran}

Tidak hanya kepala sekolah yang dituntut selalu meningkatkan kualitas kinerjanya, di era mendatang tentu tenaga pendidikpun akan dihadapkan pada persaingan yang ketat, baik bagi sekolah negeri maupun swasta. Mereka yang mempunyai kinerja yang efektif akan mendapat tempat di hati masyarakat. Oleh karenanya, bagi pendidik haruslah selalu berusaha meningkatkan kinerja karena hal ini merupakan modal untuk meningkatkan profesionalisme diri dalam menghadapi dan memenangkan persaingan personal maupun institusional sekolah.

\section{Daftar Pustaka,}

Arikunto, S. (1993). Daar-dasar Evaluasi Pendidikan Jakarta: Bumi Aksara. (1991) Psikologi Pengajaran. Jakarta: Grasindo. (2002). Prosedur Penelitian Suatu Pendekatan Praktek. Jakarta: Rineka Cipta. 
Consuello, Sevilla dkk. (1993). Pengantar Metodologi Penelitian. Jakarta: Universitas Indonesia

Departemen Pendidikan Nasional Republik Indonesia.Undang-undangIndonesia No. 20 Tahun 2003 tentang, Sistem Pendidikan Indonesia. Jakarta.

Departemen Pendidikan Nasional Indonesia. Peraturan Pemerintah No. 19 Tahun 2005 tentang standar NasionalPendidikan. Jakarta.

Gulo, W.(2002). Metodologi Penelitian. Jakarta : PT. Gramedia Widiswara Indonesia.

Indrianto, N Metodologi dan Bambang Supomo.(2002). Bisnis untuk PenelitianAkuntansi danYogyakarta: BPFE.Manajemen.

Irwanto. (1998). Psikologi umum: Buku Panduan untuk Mahasiswa, Jakarta: APTIK.

Masidjo, I. (1995). Penilaian Pencapaian HasilBelajar di Madrasah tsanawiyah, Yogyakarta:Kanisius.

Ngadirin. (8 Desember 2004). Ujian Akhir Nasional (UAN) Sebagai Issue Kritis Pendidikan [online]. Tersedia: Error! Hyperlink reference not valid. Juni 2007].

Purwantini, C. Dan Rita Eny Purwanti. (2006). Persepsi Siswa, Guru, dan Orang Tua terhadap Ujian Nasional Studi Empirik pada SMP-SMP di Kotamadya Yogyakarata. Laporan Penelitian. Yogyakarta: USD.

Santoso, S. (2003). Mengatasi berbagai MasalahStatistik dengan SPSS versi 11.5.Jakarta: ElexMedia Komputindo.

Sekaran, Uma.(2006).Metodologi Penelitian untuk Bisnis Edisi 4 Buku 2. Jakarta: salemba Empat.

Slameto: (2001). Evaluasi Pendidikan Jakarta: Bumi Aksara

Suryabrata, S. (2004). Metodologi Penelitian. Jakarta:RajaGrafindo Persada Sugiyono (2006).Statistika Bandung: Alfabeta untuk penelitian, Pendidikan

Syah,Muhibbin. (2000).PsikologiDengan Pendekatan Baru.PT. Remaja Rosdakarya. Bandung

Sudijono, A. (2005). Pengantar Evaluasi Pendidikan,Jakarta: Raja Grafindo Persada.

Tempo.(2005). Kontroversi Ujian Nasional. Tempo(4 Februari 2005).

Thoha, Miftah, (2005). Perilaku Organisasi Konsep Dasar dan Aplikasinya Jakarta RajaGrafindo Persada.

Tim Penyusun.(1991). Kamus Besar Bahasa Indonesia. Jakarta: Balai Pustaka 
Wahjosumidjo. (2002), Kepemimpinan Kepala Sekolah. Jakarta: PT Raja Grafindo Persada.

Walgito,B. (1991). Psikologi Sosial Suatu Pengantar. Yogyakarta: Andi Offset

Upaya Kepala Sekolah dalam... (Moh Tamyic)

Winarsunu, T.(2006) Statistik dalam Penelitian Psikologi dan Pendidikan. Malang: UMM Press.

Winkel (1986). Psikologi Pendidikan dan Evaluasi Belajar. Jakarta. Gramedia. 